\title{
MEDICINE
}

\section{FEATURES OF THE COURSE OF TONSILLITIS IN CHILDREN INFECTED WITH THE HERPES VIRUS}

\author{
Olkhovska V. M., Graduate students, Kharkov Medical Academy of Postgraduate Education, Kharkiv, \\ Ukraine, ORCID ID: https://orcid.org/0000-0002-8373-8224
}

Filatova A. A., Kharkov Medical Academy of Postgraduate Education, Kharkiv, Ukraine, ORCID ID: https://orcid.org/0000-0002-7480-754X

Yeloyeva Z. V., Professor, Kharkov Medical Academy of Postgraduate Education, Kharkiv, Ukraine, ORCID ID: https://orcid.org/0000-0002-4703-182X

DOI: https://doi.org/10.31435/rsglobal_ws/30062020/7105

\section{ARTICLE INFO}

Received: 11 April 2020

Accepted: 08 June 2020

Published: 30 June 2020

\section{KEYWORDS}

tonsillitis, streptococcus, herpes virus type 6 , children, clinic.

\begin{abstract}
The article presents the features of the clinical course of tonsillitis caused by hemolytic streptococcus in children infected with human herpes simplex virus type 6 (HHV 6). It was revealed that tonsillitis in children with background infection with HHV 6 is characterized by a prolonged course, prolonged maintenance of fever, impaired general condition, the presence of signs of hepatomegaly and regional lymphadenitis, and as a result, a longer stay of such patients in the hospital. The characteristic clinical and laboratory features of tonsillitis in children infected with HHV 6 include the presence in the debut of the disease subfebrile body temperature, regional lymphadenopathy, hepatomegaly, thrombocytopenia, signs of a parenchymal reaction of the liver and mesadenitis. Latent HHV 6 infection in children affects the frequency of registration and the duration of certain symptoms of tonsillitis.
\end{abstract}

Citation: Olkhovska V. M., Filatova A. A., Yeloyeva Z. V. (2020) Features of the Course of Tonsillitis in Children Infected with the Herpes Virus. World Science. 6(58), Vol.2. doi: 10.31435/rsglobal_ws/30062020/7105

Copyright: (C) 2020 Olkhovska V. M., Filatova A. A., Yeloyeva Z. V. This is an open-access article distributed under the terms of the Creative Commons Attribution License (CC BY). The use, distribution or reproduction in other forums is permitted, provided the original author(s) or licensor are credited and that the original publication in this journal is cited, in accordance with accepted academic practice. No use, distribution or reproduction is permitted which does not comply with these terms.

Tonsillitis is one of the most common diseases of childhood, they are diagnosed worldwide in about $6-8 \%$ of the outpatient population [1]. But the most common this pathology is among the children's population. It is known that the peak in the prevalence of tonsil hypertrophy and adenoid hypertrophy occurs at the age of six, and it is at this age that chronic tonsillitis is more often decompensated $[2,3]$.

Not only the acute period of tonsillitis attracts the attention of scientists, but also the likelihood of further development of the pathology of the immune system, the development of sensitization and chronic intoxication, due to the persistence of various microflora in the tonsils, the breakdown products of tissue proteins $[4,5]$.

Beta-hemolytic group A streptococci are most often isolated from the surface of the tonsils up to $30 \%[6,7]$. Many authors consider streptococcal tonsillitis in childhood as a trigger for certain somatic diseases, such as glomerulonephritis, rheumatoid arthritis, rheumatism, and others. [8, 9]. Acute rheumatic fever in $40-60 \%$ of cases leads to irreversible autoimmune damage of the heart valves and the development of chronic rheumatic heart disease [10, 11, 12, 13].

Recent decades have been characterized by an increase of children infected with herpes viruses, among which special attention is drawn to type 6 human herpes virus (HHV-6), the clinical manifestations of which vary from asymptomatic carriage to severe CNS lesions $[14,15,16]$. 
It is known that replication of HHV-6 with a horizontal transmission pathway occurs in the salivary glands, lymphoid tissue of the oropharynx and cervical lymph nodes, followed by damage to lymphocytes (up to 90\%), monocyte-macrophage and glial cells, megakaryocytes [17]. This fact explains that the reactivation of chronic HHV-6 infection is often accompanied by inflammation of the lymphoid structures of the oropharynx. The persistence of the virus in the body can also support chronic local inflammatory processes, including chronic tonsillitis in children. Therefore, we considered it appropriate to study the effect of persistence of HHV-6 on the course of tonsillitis caused by hemolytic streptococcus in children. with HHV-6.

The purpose of the work is to study the course of streptococcal tonsillitis in children infected

The study was conducted on the basis of the Regional Children's Infectious Clinical Hospital in Kharkov, where we examined 76 children aged 6 to 13 years, patients with tonsillitis due to hemolytic streptococcus group A. All patients were divided into two groups. The first group included 34 patients with tonsillitis and infected with HHV-6 (mixed infection - the main group), the second 42 children with tonsillitis without concomitant infection with any viruses (mono-infection - control group). The disease proceeded in moderate form in all children. The final diagnosis was formulated taking into account the results of clinical, bacteriological, virological and serological studies of patients. In all patients by bacteriological examination of smears from the nasopharynx and oropharynx S. pyogenes was isolated. In addition, studies of acute phase indices, ECG, ultrasound of the abdominal cavity, heart and lymph nodes (if necessary) were performed. Persistent HHV-6 infection was diagnosed if the patient had high titers of IgG antibodies to HHV-6 (latent form). PCR examination of blood serum and saliva did not detect the presence of the virus. The results of studies of patients on other herpes viruses were negative. Children of both groups were comparable in age $(9.91 \pm 1.53$ and $11.06 \pm 1.05$ years, $p>0.05)$ and gender. Static processing of the results was carried out using Excel and Statistica 6.0.

The results of the study. A comparison of the main clinical symptoms of patients showed that at the onset of the disease, in both study groups the main clinical signs were the same. In the vast majority of children, the disease began acutely with an increase in body temperature, impaired general well-being, sore throat, decreased appetite, and reaction of regional lymph nodes. We found differences in the frequency of registration and the severity of some clinical symptoms and indicators of additional examination (table. 1).

Table 1 . The main clinical and laboratory parameters of patients, (abs, \%)

\begin{tabular}{|c|c|c|c|c|c|}
\hline \multirow{2}{*}{\multicolumn{2}{|c|}{ Symptom }} & \multicolumn{2}{|c|}{ Main group $(n=34)$} & \multicolumn{2}{|c|}{ Control group $(n=42)$} \\
\hline & & abs. & $\%$ & abs. & $\%$ \\
\hline \multicolumn{2}{|c|}{1} & 2 & 3 & 4 & 5 \\
\hline \multirow{3}{*}{ Fever } & total & 34 & 44,74 & 42 & 55,26 \\
\hline & subfebrile digits & 25 & 32,90 & 14 & 18,42 \\
\hline & febrile digits & $9 *$ & 11,84 & 28 & 36,84 \\
\hline \multicolumn{2}{|c|}{ General condition disorder } & 30 & 39,47 & 37 & 48,68 \\
\hline \multicolumn{2}{|c|}{ Decreased appetite } & 28 & 36,84 & 35 & 46,05 \\
\hline \multicolumn{2}{|c|}{ Sore throat } & 28 & 36,84 & 33 & 43,42 \\
\hline \multicolumn{2}{|c|}{ Joint pain } & 15 & 19,74 & 26 & 34,21 \\
\hline \multicolumn{2}{|c|}{ Oropharynx hyperemia } & 34 & 44,74 & 42 & 55,26 \\
\hline \multicolumn{2}{|c|}{ membrane on one of the tonsils } & 8 & 10,53 & 15 & 19,74 \\
\hline \multicolumn{2}{|c|}{ Plaque on both tonsils } & 26 & 34,21 & 27 & 35,53 \\
\hline \multicolumn{2}{|c|}{ Language tightness } & 26 & 34,21 & 37 & 48,68 \\
\hline \multicolumn{2}{|c|}{ Enlarged cervical lymph nodes } & $29 *$ & 38,16 & 14 & 18,42 \\
\hline \multicolumn{2}{|c|}{ Enlarged submandibular lymph nodes } & 34 & 44,74 & 42 & 55,26 \\
\hline \multicolumn{2}{|c|}{ Generalized lymphadenopathy } & $18^{*}$ & 23,68 & 6 & 7,89 \\
\hline \multicolumn{2}{|c|}{ Difficulty in nasal breathing } & $19 *$ & 25 & 7 & 9,21 \\
\hline \multicolumn{2}{|c|}{ Hepatomegaly } & $18^{*}$ & 23,68 & 6 & 7,89 \\
\hline
\end{tabular}


Continuation of table 1 .

\begin{tabular}{|c|c|c|c|c|c|}
\hline \multicolumn{2}{|c|}{1} & 2 & 3 & 4 & 5 \\
\hline \multicolumn{2}{|c|}{ Change in heart sounds (auscultation) } & $25 *$ & 32,90 & 11 & 14,47 \\
\hline \multicolumn{2}{|l|}{ Skin rash } & $19 *$ & 25 & 7 & 9,21 \\
\hline \multicolumn{2}{|c|}{ Peripheral Neutrophilia } & $18^{*}$ & 23,68 & 34 & 44,74 \\
\hline \multicolumn{2}{|c|}{ Accelerated ESR } & 28 & 36,84 & 30 & 39,47 \\
\hline \multicolumn{2}{|c|}{ Thrombocytopenia } & $18^{*}$ & 23,68 & 6 & 7,89 \\
\hline \multicolumn{2}{|c|}{ Changes in the clinical analysis of urine } & 15 & 19,74 & 21 & 27,63 \\
\hline \multicolumn{2}{|c|}{ Increased C-reactive protein } & 23 & 30,26 & 29 & 38,16 \\
\hline \multicolumn{2}{|c|}{ Increased O-Streptolysin } & 22 & 28,95 & 34 & 44,74 \\
\hline \multicolumn{2}{|c|}{ ECG changes } & 29 & 38,16 & 28 & 36,84 \\
\hline \multirow{4}{*}{$\begin{array}{l}\text { Changes in } \\
\text { abdominal } \\
\text { ultrasound }\end{array}$} & $\begin{array}{l}\text { increased echogenicity of the } \\
\text { liver parenchyma }\end{array}$ & 18 & 23,68 & 15 & 19,74 \\
\hline & mesadenitis phenomena & $13 *$ & 17,11 & 3 & 3,94 \\
\hline & hepatitis & $14^{*}$ & 18,42 & 3 & 3,94 \\
\hline & splenitis phenomena & 3 & 3,95 & 0 & 0 \\
\hline
\end{tabular}

Note: * - probability of a sign, $\mathrm{t} \geq 2,0$.

An analysis of the medical history showed that the children of the main group were admitted to the hospital on $3.38 \pm 0.74$ days from the onset of the first symptoms of the disease, and the patients of the control group $-1.18 \pm 0.68(\mathrm{p}<0.05)$. In the history of life of patients with mixed infection, frequent respiratory infections and tonsillitis were noted ( $7.84 \pm 1.08$ times a year). The frequency of respiratory diseases in patients with mono-infection was less ( $4.08 \pm 1.17$ times a year), $\mathrm{p}<0.05$.

When children were admitted to the hospital, all children had an elevated body temperature. But in patients of the main group a subfebrile temperature reaction prevailed, while in children of the control group more often febrile numbers were recorded $(t \geq 2,0)$. Patients of the main group significantly more often noted difficulty in nasal breathing, a rash on the skin, increased cervical lymph nodes, generalized lymphadenopathy, changes in heart sounds during auscultation studies, an increase in liver size based on palpation and percussion of the abdomen $(t \geq 2,0)$. The skin rash in patients with mixed infection was mainly spotty-papular, small with a predominant location on the trunk and extremities, in three patients single petechial elements were noted. In all children, the appearance of a rash is regarded as allergic dermatitis.

An additional laboratory and instrumental examination of patients also revealed certain differences. Thus, in the study of peripheral blood indices, neutrophilia typical for bacterial infection was recorded significantly more often in patients of the control group $(34-44.74 \%$ and $18-23.68 \%$, respectively, $t \geq 2,0)$. At the same time, a decrease in platelet count was characteristic of patients in the main group $(18-23.68 \%$ and $6-7.89 \%$, respectively, $t \geq 2.0)$. We did not observe a significant difference in acute phase indices in the acute period of the disease.

Differences were found during ultrasound examination of the abdominal organs of children. Significantly more often in patients with mixed infection, the phenomena of mesadenitis and hepatitis were recorded $(t \geq 2.0)$. Additional liver tests did not reveal significant differences in the levels of cytolytic enzymes in the studied groups $(p \geq 0.05)$, although an increase in their content was determined in six patients of the main group. By the time patients were discharged from the hospital, the level of cytolytic enzymes of the liver was restored to physiological.

We have analyzed the duration of preservation of the main clinical symptoms in children. The results are presented in table. 2 .

An analysis of clinical and instrumental indicators revealed a long-term persistence of fever, symptoms of general intoxication in the form of impaired well-being and decreased appetite, hyperemia of the oropharynx, enlargement of the submandibular lymph nodes, nasal congestion, enlargement of the liver with a parenchymatous reaction of its parenchyma according to ultrasound data in patients of the main group compared with the results of children in the control group, $p<0,05$. The phenomena of hepatomegaly persisted in the vast majority of patients with mixed infection until discharge from the hospital (13$17.11 \%$ ). The revealed features of the main clinical symptoms duration in patients of the main group caused their long stay in the hospital $(10.11 \pm 0.54$ versus $8.25 \pm 0.35$ days, respectively, $\mathrm{p}<0.05)$. 
Table 2. The duration of the main symptoms, $(\mathrm{M} \pm \mathrm{m}$, day $)$

\begin{tabular}{|l|c|c|}
\hline \multirow{2}{*}{\multicolumn{1}{c|}{ Symptom }} & Main group $(\mathrm{n}=34)$ & Control group $(\mathrm{n}=42)$ \\
\cline { 2 - 3 } & $\mathrm{M} \pm \mathrm{m}$ & $\mathrm{M} \pm \mathrm{m}$ \\
\hline Fever & $6,14 \pm 0,67^{*}$ & $4,24 \pm 0,24$ \\
\hline General condition disorder & $5,23 \pm 0,37^{*}$ & $3,53 \pm 0,42$ \\
\hline Decreased appetite & $4,47 \pm 0,11^{*}$ & $3,18 \pm 0,27$ \\
\hline Sore throat & $4,08 \pm 0,28$ & $4,28 \pm 0,67$ \\
\hline Joint pain & $2,21 \pm 0,38$ & $2,97 \pm 0,34$ \\
\hline Oropharynx hyperemia & $6,81 \pm 0,64^{*}$ & $5,03 \pm 0,42$ \\
\hline Tonsil coating & $3,06 \pm 0,33$ & $3,97 \pm 0,44$ \\
\hline Language tightness & $5,25 \pm 0,35$ & $4,84 \pm 0,27$ \\
\hline Enlarged submandibular lymph nodes & $7,27 \pm 0,54^{*}$ & $5,81 \pm 0,35$ \\
\hline Nasal congestion & $4,25 \pm 0,51^{*}$ & $1,98 \pm 0,43$ \\
\hline Hepatomegaly & $8,47 \pm 0,41^{*}$ & $4,21 \pm 0,50$ \\
\hline Parenchymal liver reaction & $8,06 \pm 0,29^{*}$ & $4,42 \pm 0,38$ \\
\hline Duration of hospital stay & $10,11 \pm 0,54^{*}$ & $8,25 \pm 0,35$ \\
\hline
\end{tabular}

Note: * - probability of a sign, $\mathrm{p}<0,05$.

Thus, the course of tonsillitis caused by S. ryogenes in children against the background of infection with HHV type 6 is characterized by a number of clinical, laboratory and instrumental features. In the history of such children, frequent respiratory infections and tonsillitis occur. Patients with tonsillitis due to infection with HHV type 6 are later admitted to the hospital, which, in our opinion, is associated with subfebrile temperature in the onset of the disease in these children, while in patients with mono-infection febrile fever is more often recorded. The features of tonsillitis in children infected with HHV type 6 also include difficulty in nasal breathing, a rash on the skin, an increased cervical lymph nodes, generalized lymphadenopathy, changes in heart sounds, hepatomegaly, and the absence of changes typical of a bacterial infection in the analysis of peripheral blood with frequent thrombocytopenia, as well as the phenomena of mesadenitis and hepatitis according to the results of ultrasound. Children with tonsillitis and HHV infection 6 are characterized by a prolonged preservation of the main clinical symptoms, leading to a prolongation of their hospital stay.

Our results will allow to detect the persistence of HHV type 6 in children in the early stages of tonsillitis without the use of specific expensive studies that are not always available to the population, which will contribute to the timely improvement of therapy and clinical observation of patients.

Conclusions. 1. Latent HHV 6 infection in children affects the frequency of registration and the duration of certain clinical and laboratory symptoms of tonsillitis caused by S. pyogenes.

2. The main features of tonsillitis in children infected with HHV type 6 include an subfebrile body temperature, difficulty in nasal breathing, a rash on the skin, an increase in cervical lymph nodes, generalized lymphadenopathy, changes in heart sounds, hepatomegaly, thrombocytopenia, and the absence of a shift in the blood count to the left, and also the phenomena of mesadenitis and hepatitis according to the ultrasound.

3. Tonsillitis in children infected with HHV type 6 is characterized by a longer course of the disease, which leads to a longer hospital treatment.

4. The revealed features of the course of tonsillitis in children against the background of infection with HHV type 6 dictate the need to improve the treatment and rehabilitation of such patients.

\section{REFERENCES}

1. Nayak Vijayakumar. Traditional medicine in the management of recurrent tonsillitis - an ayurvedic perspective./ Nayak Vijayakumar, Jadhav Vinod, M.R. Sajjanshetty.// Journal of Ayurveda and Integrated Medical Sciences. - 2017 November - December 2 (6). ISSN 2456-3110.

2. Белов В.А., Воропаева Я.В. // Возрастные и гендерные особенности распространенности хронического тонзиллита у детей // Медицинский совет. - 2015.- № 1. - С. 18-21.

3. Данилов Л.А., Гинда С.С., Абабий И.И. //Диагностика компенсированного и декомпенсированного тонзиллита у детей в зависимости от возраста //Оториноларингология. Восточная Европа. - 2014.№ 3 (16). C. 131-135. 
4. Машкова Т.А., Сорокина М.С., Мальцев А.Б. //Факторы риска развития абдоминальных осложнений острого и хронического тонзиллита у детей //Российская оториноларингология. - 2019. Т. 18, № 4 (101). C. 75-81.

5. Smiyan O.I., Mozgova Yu.A., Moshchych O.P. //Effect of acidolac junior on intestinal microflora of children with chronic tonsillitis //Здоровье ребенка. - 2013.- № 7 (50). C. 20-24.

6. Nuha Saad H Alasmari, Ryan Omar M Bamashmous, et al. // Causes and Treatment of Tonsillitis. //The Egyptian Journal of Hospital Medicine. - 2017 Oct;69(8):2975-2980.doi: 10.12816/0042838.

7. Yegin Y, Çelik M, et al. //The relationship between tonsillar size and neutrophilto-lymphocyte ratio in children with recurrent tonsillitis. //Otolaryngol Open J. 2016;2(5):120-124. doi:10.17140/ OTLOJ-2-127.

8. Luisa Zupinab. DEFB1 polymorphisms and susceptibility to recurrent tonsillitis in Italian children./ Luisa Zupinab, et al.// International Journal of Pediatric Otorhinolaryngology. - 2016 Apr; 83:12-15. https://doi.org/10.1016/j.ijporl.2016.01.025.

9. Raja Kalaiarasi. Microbiological Profile of Chronic Tonsillitis in the Pediatric Age Group./ Raja Kalaiarasi. Kalaivani S Subramanian, et al.// Cureus. - 2018 Sep;10(9):e3343. doi: 10.7759/cureus.3343. PMCID: PMC6248716; PMID: 30473976.

10. JR Carapetis. Acute rheumatic fever and rheumatic heart disease./ JR Carapetis, et al.// Nature Reviews. Disease Primers. - 2016;2:15084. doi: 10.1038/nrdp.2015.85

11. Марушко Ю.В., Гищак Т.В., Лисовець О.В., Марушко Є.Ю., //Досвід застосування імуномодулюючої терапії в комплексному лікуванні хронічного тонзиліту в дітей // Здоров'я дитини. - 2015. №1 (60) С. 49-53.

12. Giuseppe Gregori. Reduction of group A beta-hemolytic streptococcus pharyngo-tonsillar infections associated with use of the oral probiotic Streptococcus salivarius K12: a retrospective observational study./ Giuseppe Gregori, Ornella Righi, Paolo Risso, et al.// Ther Clin Risk Manag. - 2016; 12:87-92. doi: 10.2147/TCRM.S96134. PMCID: PMC4725641; PMID: 26855579.

13. Baymakova M. Medical history among bulgarian patients with fever of unknown origin and low-grade fever./ Baymakova M., Plochev K., Kundurdjiev T., Popov G.T., Mihaylova-Garnizova R., Kovaleva V.// Варненский медицинский форум. - 2016. Т. - 5, № 2. С. 46-52.

14. Крамарьов С.О, Свтушенко В.В., //Сучасні підходи до лікування герпетичної інфекції в дітей. //Актуальная инфектология. - 2019. Т. 7. №3. С. 37-40.

15. Рассказова О.М, Рибак I.P, Ворожко Т.А, Пономаренко В.В, Мальцев Д.В. //Хронічна вірусна інфекція, спричинена вірусом герпесу 6 типу, з ураженням нервової системи на тлі дефіциту природних кілерів.//Клінічна імунологія. Алергологія. Інфектологія. - 2017. №5 (102). С. 27-33.

16. Cohen J.I. Human, //Herpesvirus Types 6 and 7 (Exanthem Subitum). //Mand Douglas, Bennett's Princ. Pract. Infect Dis. - 2015 Jan: e1772-1776. doi: 10.1016/B978-1-4557-4801-3.00142-9.

17. Щубелко Р.В, Зуйкова И.Н, Шульженко А.Е. // Герпесвирусные инфекции человека: клинические особенности и возможности терапии. // РМЖ. - 2018. №8(I). С. 39-45. 